\title{
Лагунные берега Тихоокеанской России: факторы эволюции и природопользование
}

\author{
БРОВКО П.Ф. ${ }^{1}$, ДЗЕН Г.Н. ${ }^{2}$, ЖУКОВИНА М.Г. ${ }^{1}$, МАЛЮГИН А.В. ${ }^{1}$ \\ ${ }^{1}$ Федеральное государственное автономное образовательное учреждение высшего образования \\ «Дальневосточный федеральный университет», Владивосток \\ ${ }^{2}$ Сахалинский филиал Федерального государственного бюджетного научного учреждения \\ «Всероссийский научно-исследовательский институт рыбного хозяйства и океанографии», \\ Южно-Сахалинск \\ peter.brofuko@yandex.ru
}

Аннотация. Прибрежная зона восточно-арктических и дальневосточных морей Тихоокеанской России имеет широкий спектр морфогенетических типов берегов. Наиболее полно среди них представлены лагунные берега. Эволюция лагун связана с повышением уровня Мирового океана. На этом фоне отмечено увеличение штормовой активности, что приводит к существенному преобразованию рельефа: формированию новых проливов и островов, преобразованию дельт. Существенно проявление географической зональности в динамике берегов. Показано, что в Охотском море ледовый фактор играет важную роль в морфологии и динамике лагун, а природные условия формирования побережий позволяют считать их субарктическими.

Прибрежно-морское природопользование носит разносторонний характер: добыча рыбы, водорослей и беспозвоночных; гидротехническое строительство; разработка прибрежно-морских россыпей тяжелых металлов; освоение бальнеологических ресурсов. Широко развиты марикультура и экологический туризм. Лагунные берега формируются иногда в условиях активного техногенного воздействия.

Ключевые слова: лагунные берега, восточно-арктические моря, дальневосточные моря, эволюция берегов, прибрежно-морское природопользование.

\section{The lagoon shores of the Pacific Russia: factors of sea coast evolution and nature management}

\author{
BROVKO P.F. ${ }^{1}$, DZEN G.N. ${ }^{2}$, ZHUKOVINA M. G. ${ }^{1}$, MALYUGIN A.V. ${ }^{1}$
}

${ }^{1}$ Far Eastern Federal University, Vladivostok

${ }^{2}$ Sakhalin research Institute of Fisheries and Oceanography, Yuzhno-Sakhalinsk peter.brofuko@yandex.ru

\begin{abstract}
The coastal zone of the East Arctic and Far-Eastern seas of Pacific Russia has a wide range of the morphogenetic types of the shores. The lagoon shores are most fully presented among them. The lagoons evolution is caused by the world ocean level increase. An increase in storm activity leads to a significant transformation of the terrain. New straits and islands are formed and the deltas are transformed. The manifestation of the geographic zonality in the dynamics of shores is essential. It is shown that the ice factor plays an important role in the morphology and dynamics of lagoons in the Sea of Okhotsk. The natural conditions for the formation of coasts make it possible to consider them as subarctic. The coastal-marine management is of versatile nature: catch of fish, algae and invertebrates; hydrotechnical construction; mining of seashore placers of the heavy metals; development of balneal resources. The mariculture and ecotourism are well represented. Sometimes the lagoon shores are formed under conditions of active technogenic impact.
\end{abstract}

Keywords: lagoon shores, East Arctic seas, Far Eastern seas, shore evolution, coastal-marine management. 


\section{Введение}

Лагунные берега широко распространены на побережье Мирового океана, занимают в отдельных регионах до $10-20 \%$ от общей протяженности $[1,2]$. Лагуны, как отчлененные от моря береговыми барами, косами, пересыпями морские заливы, являются сложными геосистемами, в которых существенно взаимодействуют явления и процессы, характерные для контактной зоны «суша - море». С одной стороны, весьма велико влияние речного твердого стока, что приводит иногда к формированию дельт и полному заполнению водоемов осадочным материалом. С другой, приливные течения иногда существенно меняют в течение суток соленость - от морской воды в 33-35 \%о до практически пресной, что выдерживают не все виды организмов, обитающих на границе суши и моря.

Тем не менее выровненный рельеф побережья, более прогреваемая по сравнению с открытым морем вода мелководной акватории, наличие лечебных грязей, высокая защищенность от штормового воздействия открытого моря, уникальные биоценозы и т.д. делают лагунные берега весьма привлекательными для гидротехнического и транспортного строительства, развития рекреационной деятельности, включая экологический туризм, создания хозяйств марикультуры. В последние годы лагунные берега, активно реагирующие на колебания уровня Мирового океана, вызывают интерес исследователей по разным аспектам геоморфологии, эволюции, природопользования [3-6 и др.].

\section{Материалы и методы}

Лагунные берега исследуются в Дальневосточном государственном университете (с 2012 г. - Дальневосточный федеральный университет) в течение полувека. Полевые работы с оценкой динамики лагунных форм рельефа проводились на Чукотке, Камчатке, Курильских и Шантарских островах, в Приморье.

Основным объектом исследования являются лагуны о-ва Сахалин, где они занимают пятую часть побережья. Экспедиционные работы выполнялись с использованием маломерного флота, геодезического оборудования и GPS, с отбором проб пляжевых и донных осадков лагун для лабораторного исследования.

Применялся широкий спектр лабораторных работ: гранулометрический, диатомовый, спорово-пыльцевой анализы. Оценивался химический состав морских, речных, лагунных вод, лечебных грязей. На Сахалине геоморфологический лагунный мониторинг с широким применением аэрометодов и материалов космической съемки проводится в 10 пунктах между $46^{\circ} 20^{\prime}$ и 53 50' с.ш. Полный цикл наблюдений проведен в 2006-2007 гг. на севере и 2015-2016 гг. на юге Сахалина.

Для анализа зональных различий формирования лагунных берегов широко использовались сравнительно-географический и картографический методы с привлечением материалов дистанционного зондирования. Всего в базе данных две сотни дальневосточных лагун

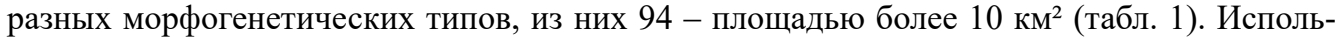
зованы как литературные источники, так и материалы полевых исследований авторов в тихоокеанских штатах США, Японии и Социалистической Республике Вьетнам $[3,4,7,8]$.

Таблица 1

Лагуны дальневосточных морей площадью более 10 км²

Table 1. The lagoons of the Far Eastern seas

\begin{tabular}{|c|l|c|c|c|}
\hline № & \multicolumn{1}{|c|}{ Море } & $\mathbf{1 0 - 1 0 0}$ км$^{\mathbf{2}}$ & $\mathbf{1 0 0 - 5 0 0} \mathbf{~} \mathbf{~}^{\mathbf{2}}$ & Более 500 км$^{\mathbf{2}}$ \\
\hline 1 & Восточно-Сибирское & 9 & 2 & - \\
\hline 2 & Чукотское & 6 & 7 & 1 \\
\hline 3 & Берингово & 27 & 7 & 4 \\
\hline 4 & Охотское & $6+8^{1}$ & $2+6^{1}$ & $1^{1}$ \\
\hline 5 & Японское & $2+2^{1}$ & 1 & - \\
\hline Всего: & & 60 & 28 & 6 \\
\hline
\end{tabular}

${ }^{1}$ Лагуны острова Сахалин. 


\section{Постановка проблемы}

Для морей восточного сектора Арктики характерно распространение дельтовых, термоабразионных берегов и различных типов лагун. Последние отделены от моря береговыми барами, сложенными гравийно-галечным материалом и пересыпями сложного строения, с включениями коренных участков суши. Бары отчленяют обширные акватории лагун приморских низменностей севера Чукотского полуострова, морей Лаптевых и Восточно-Сибирского [9].

В условиях полярного климата акватории лагун большую часть года покрыты льдом, который препятствует интенсивному перемешиванию вод и создает благоприятные условия для сероводородного заражения придонных вод и донных отложений. Последние представляют собой илистые осадки, обогащенные неокатанным щебнистым материалом различной крупности [10].

Суровые климатические условия не способствуют активному росту органической массы в акваториях лагун. Заполнение лагун осадками происходит преимущественно за счет твердого стока рек, эолового переноса и поступления пляжевого материала с мористой стороны при сильных штормах.

Крупнейшей береговой аккумулятивной формой, обусловившей выровненность береговой линии северного побережья Анадырского залива, является коса Мээчкын, протягивающаяся на 76 км вдоль низкого берега на восток от залива Креста. Считается, что она представляет собой береговой бар, сформированный в результате поперечного перемещения наносов. Они вовлекаются во вдольбереговые дивергентные перемещения, наращивая бар косами с противоположных концов [1].

Абразионно-аккумулятивные берега широко распространены на побережье Корякского нагорья. За счет размыва входных мысов бухт, реже - в результате поступления наносов со дна, образовались многочисленные пересыпи и бары, отчленившие фиорды от моря, - лагуны Лахтина, Аринай, Амаам, а также озера Ыстигет и Тюленье, лагуны Кивак и Имтук, озеро и лагуна Аччен [1]. Пересыпи рассечены извилистыми протоками, соединяющими озера-лагуны с морем.

В морфологии и динамике берегов Восточной Камчатки ярко выражено лопастное расчленение побережья, связанное с системами разломов и сбросов. Выдвинутые в море горстовые поднятия полуостровов Озерного, Камчатского, Кроноцкого и Шипунского чередуются с открытыми береговыми дугами большого радиуса. Клифы здесь местами отмершие, окаймлены широкими бенчами с гравийно-галечными пляжами [1]. Аккумулятивные формы представлены надводными террасами, отчленяющими лагуны от моря пересыпями с песчаными пляжами. На Шипунском полуострове расположены самые южные в Северном полушарии лагуны-фиорды.

Побережье Западной Камчатки имеет относительно простое строение, и на нем можно выделить два береговых района, границей которых служит мыс Хайрюзова. Южнее мыса на протяжении свыше 600 км полого-выпуклая к западу дуга представляет собой чередование коренных участков берега и протяженных баров-пересыпей, за которыми расположены длинные «шнурообразные» лагуны и лагуны-эстуарии[6, 11].

Непосредственно к северу от мыса Хайрюзова береговая линия в плане образует ряд вогнутых дуг. Они опираются своими концами на выступающие в море мысы, сложенные базальтами и андезитами, в то время как сами дуги выработаны волнами в туфогенных песчаниках и конгломератах. Аккумулятивные береговые формы в этих дугах сравнительно невелики по размерам и представлены косами и примкнувшими современными террасами.

Рельеф береговой зоны северного побережья Охотского моря в настоящее время приобрел черты зрелости, хотя береговая линия так и не испытала выравнивания в силу своей глубокой расчлененности. Причиной этого являются большая устойчивость горных пород к абразии, преобладание восходящих вертикальных движений побережья и сравнительно небольшой твердый сток рек. 
На северо-западном побережье Охотского моря встречаются абразионные выровненные, абразионно-бухтовые и абразионно-аккумулятивные типы берегов. Обширные аккумулятивные участки с лагунами встречаются в вершинах бухт, куда впадают крупные реки. На мысах преобладают высокие скалистые клифы с узким бенчем и пляжами, сложенными грубообломочным материалом.

Берега Сахалинского залива более выровнены благодаря широкому распространению кос и пересыпей самых различных очертаний и генезиса. Сахалинский залив наряду с Амурским лиманом, проливами Татарским и Невельского является частью одной из крупнейших в бассейне Тихого океана проливных систем протяженностью в тысячу километров. Существенное влияние на формирование рельефа дна и распределение грунтов в северной части системы оказывают приливные течения.

В Японском море развиты риасовые, аккумулятивные ровные, лагунные, ровные абразионные и абразионно-бухтовые берега [1].

Эволюция морских берегов в последнее столетие при прочих равных условиях является следствием повышения уровня Мирового океана. На берегах Тихоокеанской России - от востока Арктики до Японского моря - происходит преобразование рельефа прибрежной зоны с сохранением общей тенденции отступания береговой линии и сокращения площади прибрежной суши [7]. Как показал В.П. Зенкович, берега дальневосточных морей формируются в различных морфоструктурных, гидродинамических и зональных условиях и многообразны по морфодинамике и особенностям эволюции [2].

При подъеме уровня моря на побережьях Западной Камчатки, Северо-Западного Приохотья и Восточного Сахалина процессы развития береговой линии будут протекать унаследовано, т.е. барьерные формы будут перемещаться в сторону суши с размывом их фронтальных частей, а береговая линия в целом выравниваться $[3,12,13]$. В зависимости от местных условий, например значительного дефицита наносов, активизация размыва может привести к полному разрушению аккумулятивных форм на отдельных участках и прорыву моря в береговые лагуны.

\section{Результаты и их обсуждение}

Крупные прорывы барьерных форм отмечены нами для лагунных берегов на северо-востоке Сахалина. Два участка размыва пересыпей превратили их в острова. Возникший в 2004 г. новый остров в лагуне Даги предложено назвать именем выдающегося ученого, специалиста по морским берегам В.П. Зенковича (утверждено постановлением Правительства РФ 3.10.2017), а пролив - именем известного исследователя берегов Сахалина А.Т. Владимирова (рис. 1).

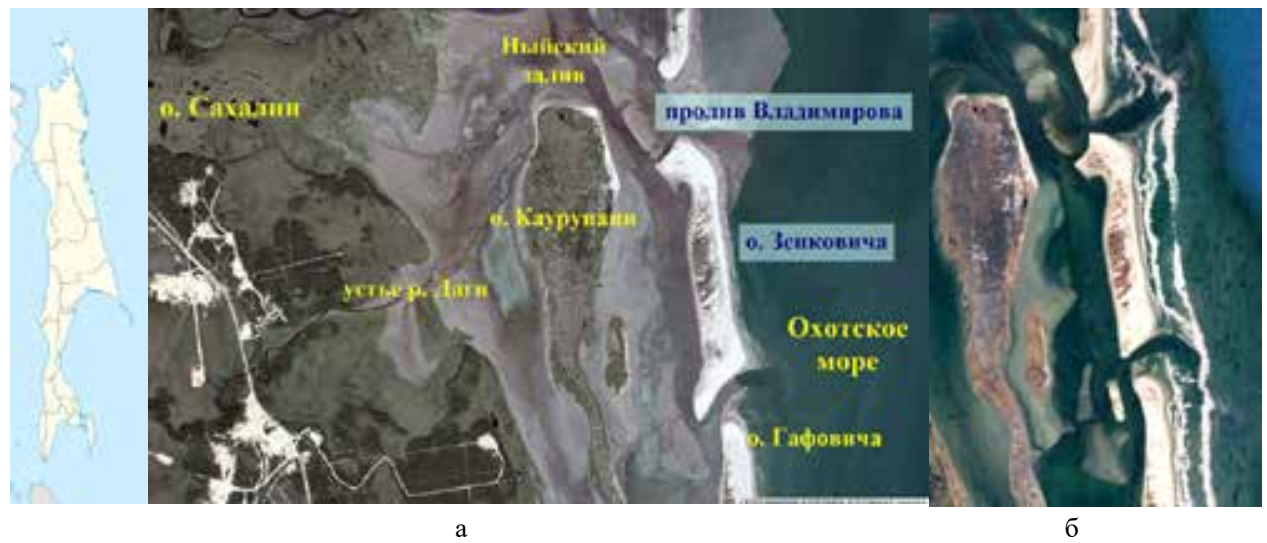

Рис. 1. Новый пролив (Владимирова) и остров (Зенковича) на северо-востоке о-ва Сахалин (52 $06^{\prime}$ с.ш.) (а - 2012 г., б-2019 г.)

Fig. 1. New Strait (Vladimirov) and the island (Zenkovich) in the north-east of Sakhalin Island $\left(52^{\circ} 06^{\prime} \mathrm{N}\right)(\mathrm{a}-$ 2012, b-2019) 


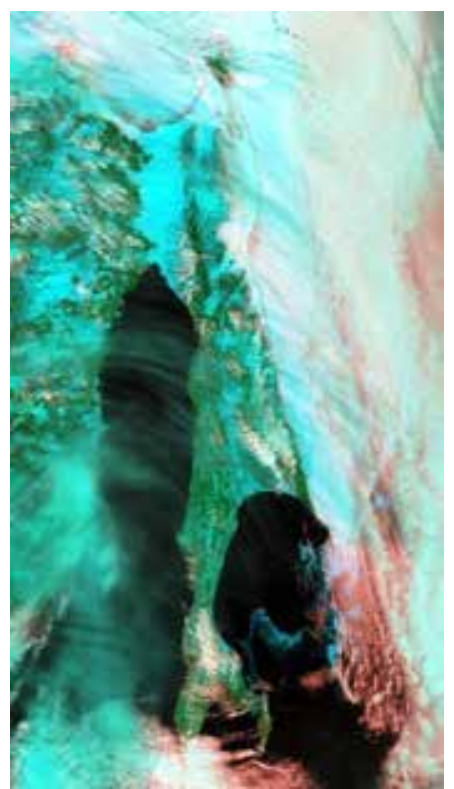

Рис. 2. Ледовая обстановка у о-ва Сахалин (Космический снимок, 23.02.2012)

Fig. 2. Ice conditions near the island of Sakhalin (Space image, 02/23/2012)
Вопросы зональности береговых процессов представлены в работах отечественных ученых: В.П. Зенковича, П.А. Каплина, Г.А. Сафьянова, А.С. Ионина, В.С. Медведева, Ю.А. Павлидиса и др. В.И. Лымарев предложил выделять в нашей стране по зональным различиям ряд береговых зон: арктико-нивальную (ледяную), субарктико-нивальную переходную (многолетнемерзлую), бореальную гумидно-нивальную (умеренно-холодную), суббореально-гумидную (умеренно-теплую), субтропико-средиземноморскую, гумидно-семиаридную, субтропико-аридную [13].

И если Восточно-Сибирское и Чукотское моря относятся к первой зоне, а север Японского моря - к бореальной гумидно-нивальной, то вопрос о разделении береговых зон в Охотском море до настоящего времени является дискуссионным. В.И. Лымарев относит Берингово море и северную часть Охотского к субарктико-нивальной зоне, не указывая ее южной границы. На карте климатических зон, учитывающих и особенности ледового режима акваторий, к субарктической зоне относятся залив Шелихова и шельф Западной Камчатки (Атлас океанов. Тихий океан, 1974, с. 126). Во многих работах по гидрографии и физической географии указывается на сложные ледовые условия в западной части Охотского моря (от Удской губы до Сахалинского залива), что реально соответствует Субарктике.

Рекреационно-геоморфологические системы (РГС) лагунных побережий Востока Азии

Table 2. Recreational-geomorphological systems (RGS) of the lagoon coasts of eastern Asia

\begin{tabular}{|c|l|c|l|l|}
\hline $\begin{array}{c}\text { № } \\
\text { п/п }\end{array}$ & \multicolumn{1}{|c|}{ Название РГС } & $\begin{array}{c}\text { Длина, } \\
\text { км }\end{array}$ & $\begin{array}{l}\text { Лагуны и прибрежные озера в } \\
\text { составе РГС }\end{array}$ & $\begin{array}{l}\text { Рекреационный } \\
\text { потенциал }\end{array}$ \\
\hline 1 & $\begin{array}{l}\text { Уэленская } \\
\text { Чукотское море, } 66^{\circ} 10^{\prime} \text { с.ш. }\end{array}$ & 44 & Уэлен, Инчоун & $\begin{array}{l}\text { МП, ЛР, } \\
\text { ЗР, ЭТ }\end{array}$ \\
\hline 2 & $\begin{array}{l}\text { Пэкульнейская } \\
\text { Берингово море, } 62^{\circ} 35^{\prime} \text { с.ш. }\end{array}$ & 57 & $\begin{array}{l}\text { Пэкульнейское, Ваммъечгын, } \\
\text { Кейпильгин }\end{array}$ & $\begin{array}{l}\text { МП, ЛР, } \\
\text { 3Р, ООПТ }\end{array}$ \\
\hline 3 & $\begin{array}{l}\text { Большерецкая } \\
\text { Охотское море, } 52^{\circ} 35^{\prime} \text { с.ш. }\end{array}$ & 41 & Большое & $\begin{array}{l}\text { СО, ЛР, } \\
\text { ЗР, ЭТ }\end{array}$ \\
\hline 4 & $\begin{array}{l}\text { Байкальская } \\
\text { Охотское море, } 53^{\circ} 35^{\prime} \text { с.ш. }\end{array}$ & 57 & Байкал, Помрь & $\begin{array}{l}\text { СО, ЛР, } \\
\text { ЗР, ЭТ }\end{array}$ \\
\hline 5 & $\begin{array}{l}\text { Ныйская } \\
\text { Охотское море, } 52^{\circ} 05^{\prime} \text { с.ш. }\end{array}$ & $\begin{array}{l}\text { Буссе-Вавайская } \\
\text { Охотское море, } 46^{\circ} 35^{\prime} \text { с.ш. }\end{array}$ & $\begin{array}{l}\text { Ныйво, Даги } \\
\text { ЛР, ЗР, ООПТ }\end{array}$ \\
\hline 7 & $\begin{array}{l}\text { Посьетская } \\
\text { Японское море, } 42^{\circ} 40^{\prime} \text { с.ш. }\end{array}$ & 31 & $\begin{array}{l}\text { Буссе, Бол. Вавайское, Мал. } \\
\text { Вавайское, Бол. Чибисанское, } \\
\text { Мал. Чибисанское }\end{array}$ & $\begin{array}{l}\text { ПК, ЛР, ЗР, ЭТ, } \\
\text { МК, ООПТТ }\end{array}$ \\
\hline 8 & $\begin{array}{l}\text { Сарома } \\
\text { Охотское море, } 44^{\circ} 05^{\prime} \text { с.ш. }\end{array}$ & 44 & Сарома, Ноторо & $\begin{array}{l}\text { ПК, ЛР, ЗР, } \\
\text { ЭТ, МК, ООПТ }\end{array}$ \\
\hline 9 & $\begin{array}{l}\text { Тамзянг } \\
\text { Южно-Китайское море, } 16^{\circ} 25^{\prime} \text { с.ш. }\end{array}$ & 63 & $\begin{array}{l}\text { Тамзянг, Каухай, Тхюиту, Чуон } \\
\text { МК, ЭТ, ООПТ }\end{array}$ & $\begin{array}{l}\text { ПК, ЛР, } \\
\text { МК, ЭТ, ООПТ }\end{array}$ \\
\hline
\end{tabular}

'Рекреационные ресурсы: бальнеологические (БЛ), пляжно-купальные (ПК), спортивно-охотничьи (СО). Виды деятельности: летняя рыбалка (ЛР), зимняя рыбалка (ЗР), марикультура (МК), морские промыслы (МП), экотуризм (ЭТ). Особо охраняемые природные территории (ООПТ).

Составлено по: [5, 7, 15 и др.]. 


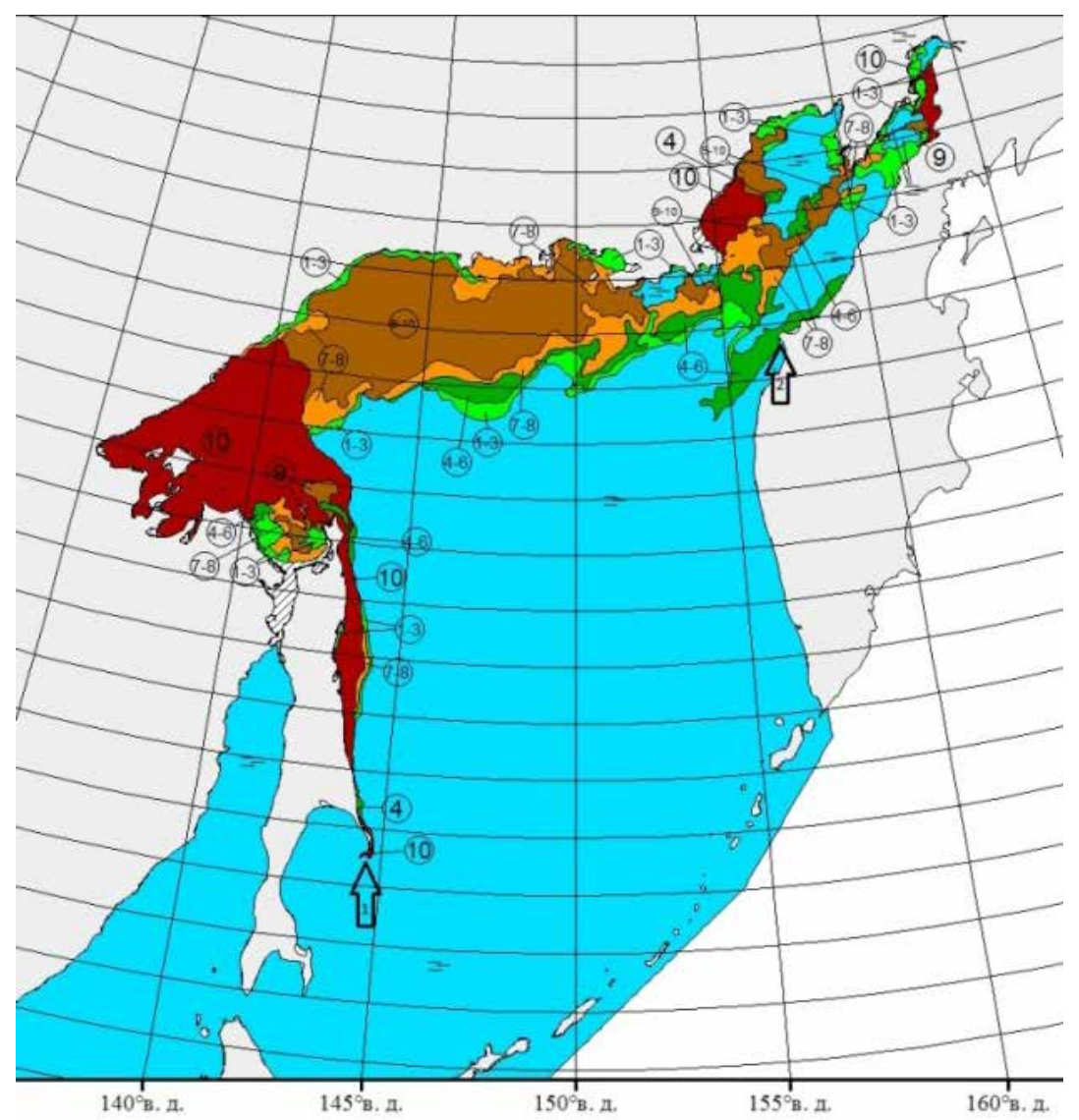

Рис. 3. Ледовая обстановка в Охотском море (17.05.2016) [14]. Стрелками обозначены: 1 - мыс Терпения; 2 - мыс Южный

Fig. 3. Ice conditions in the Sea of Okhotsk (05.17.2016) [14]. The arrows indicate: 1 - Patience Cape; 2 - Yuzhny Cape

Выполненный анализ ледовых условий по разным сезонам года (по данным Л.П. Якунина, В.М. Пищальника, В.С. Тамбовского и др.) показал, что льды в Охотоморье встречаются с октября по август. Мощный ледовый покров формируется в западной части Охотского моря (рис. 2). Залив Терпения при этом и Татарский пролив Японского моря в отдельные годы бывают зимой свободны ото льда.

В конце весны и начале лета лед как морфодинамический фактор продолжает влиять на береговые процессы в северной части Охотского моря и вдоль восточного побережья Сахалина. Причем «бронированные» осыпями снежники отмечались нами на северо-востоке острова в июне-июле. Это позволяет сделать вывод, что условия, близкие к субарктическим, характерны для значительной части Охотского моря, а их южная граница располагается по линии мыс Терпения - мыс Южный (рис. 3).

Лагунные водоемы Тихоокеанской России являются объектами активного экономического освоения. Это рыбохозяйственный комплекс, транспортное обеспечение, марикультура, развитие туризма.

В лагунах и устьях рек Кухтуй, Иня, Охота добывается сельдь тихоокеанская. В лагунах Счастья, Помрь, Ныйво и др. ведется любительский, а местами и промышленный лов корюшки азиатской В лагунном озере Пэкульнейском (Берингово море) площадью 435 км² обитает крупная популяция нерки, являющейся объектом промысла [5].

В лагунах Байкал, Набиль, Ныйво, Буссе осуществляются в небольших объемах перевозки грузов и пассажиров. На пересыпях лагун проложены дороги и трубопроводы, есть 
взлетно-посадочные полосы местных аэродромов. Лагунные проливы как естественные природные каналы для судоходства требуют постоянного гидрографического обеспечения.

Марикультура развита в отчлененных или относительно защищенных от штормового волнения водоемах преимущественно Охотского и Японского морей. Наибольшее развитие получило создание хозяйств для выращивания беспозвоночных и промысловых водорослей, строительство рыборазводных заводов по воспроизводству лососевых видов рыб [7].

Рекреационно-геоморфологические системы лагунных побережий дают широкие возможности для развития индустрии отдыха и туризма (табл. 2). Наиболее активно такие проекты реализуются в южных субъектах Дальневосточного федерального округа - в Приморском и Хабаровскомкраях, в Сахалинской области.

Водно-болотные угодья и уникальные геоморфологические объекты лагунных побережий дальневосточных морей входят в состав особо охраняемых природных территорий - заповедников и заказников. Десятки лагун являются полностью или частично памятниками природы. Только в Сахалинской области это «Лагуна Буссе», «Озеро Тунайча», «Остров Лярво», «Остров Чайка», «Лунский залив» и др. Предлагается создать национальный парк «Тунайчинский» $[4,11]$.

\section{Заключение и выводы}

Дальневосточные моря - практически идеальный объект для исследования места и значения географической зональности в динамике берегов - от северной границы субропиков до Субарктики. Показано, что в Охотском море ледовый фактор играет важную роль в морфологии и динамике лагун, а природные условия формирования побережий позволяют считать их субарктическими.

Нами отмечены крупные прорывы барьерных форм для лагунных берегов на северовостоке Сахалина, что является отражением глобальной тенденции повышения уровня Мирового океана. Существенное увеличение штормовой активности в прибрежно-шельфовой зоне приводит к значительному преобразованию рельефа: формированию новых проливов и островов, динамике дельт. Это создает определенные трудности для судоходства и выделения рыбопромысловых участков в прибрежном рыболовстве.

Прибрежно-морское природопользование в Тихоокеанской России носит разносторонний характер: добыча рыбы, водорослей и беспозвоночных; гидротехническое строительство; разработка прибрежно-морских россыпей тяжелых металлов; освоение бальнеологических ресурсов. Широко развиты марикультура и прибрежно-морской экологический туризм.

Лагунные берега часто формируются в условиях активного влияния хозяйственной деятельности. Этому способствуют выровненный рельеф аккумулятивного побережья, многообразие минеральных, биологических, рекреационных ресурсов. Сложная экологическая ситуация создается в районах освоения нефтегазоносного шельфа. В направлении с севера на юг увеличивается спектр видов природопользования и возрастает роль антропогенного фактора в динамике берегов.

Работа выполнена по гранту РФФИ № 18.05.80006/18 «Пространственная дифференциация факторов, условий и ограничений формирования и развития структур природопользования в прибрежной зоне Тихоокеанской России с учетом воздействия экстремальных (опасных) природных проиессов и явлений.

\section{Литература}

1. Берега Тихого океана / под ред. В.П. Зенковича. М.: Наука, 1967. 373 с.

2. Зенкович В.П. Основы учения о развитии морских берегов. М.: Изд-во АН СССР, 1962. 710 с.

3. Бровко П.Ф. Развитие лагунных берегов дальневосточных морей в условиях повышения уровня океана // Материалы XIV Совещ. географов Сибири и Дальнего Востока. Владивосток: Дальнаука, 2011. С. 11-14. 
4. Бровко П.Ф., Васина М.В., Дзен Г.Н., Жуковина М.Г., Малюгин А.В., Меньчик А.А. Лагуны острова Сахалин - уникальные объекты природного наследия // Региональные аспекты географических исследований и образования: сб. статей. Пенза: Изд-во ПГУ, 2019. С. 92-95.

5. Бугаев В.Ф., Кириченко В.Е. Нагульно-нерестовые озера азиатской нерки (включая некоторые другие водоемы ареала). Петропавловск-Камчатский: Камчатпресс, 2008. 280 с.

6. Горин С.Л., Коваль М.В. Лагуны в приливных устьях рек Камчатки и Корякии // Арктические берега: путь к устойчивости. Мурманск: МАГУ, 2018. С. 44-47.

7. Бровко П.Ф. Рекреационно-геоморфологические системы лагунных берегов Сахалина // Вестн. Сахалин. областного краевед. музея. 2013. № 20. С. 190-196.

8. Бровко П.Ф., Нгуен Хыу Шиу, Чинь Тхе Хиеу. Геоморфология и динамика берегов провинции Фукхань (СРВ) // Береговая зона дальневосточных морей: сб. науч. тр. Л., 1991. С. 119-127.

9. Арктический шельф. Позднечетвертичная история как основа прогноза развития / Ю.А. Павлидис, А.С. Ионин, Ф.А. Щербаков и др. М.: Геос, 1998. 187 с.

10. Жиндарев Л.А. Особенности эволюции лагунных побережий Чукотского и Балтийского морей // Вестн. МГУ. Серия 5, геогр. 1984. № 3. С. 85-87.

11. The Diversity of Russian Estuaries and Lagoons Exposed to Human Influence / R. Kosyan, P. Brovko, Yu. Mikishinetall. Springer International Publishing AG Switzerland, 2017. 270 p.

12. Владимиров А.Т. Морфология и эволюция лагунного берега острова Сахалина // Тр. ИОАН СССР. T. 48, 1961. C. $145-171$.

13. Лымарев В.И. Северный Ледовитый океан: геосистемный аспект. Архангельск: Поморский госуниверситет им. М.В. Ломоносова, 2003. 247 с.

14. Ледовая карта Охотского моря // ФГБУ «ААНИИ» [Электронный ресурс]. - Режим доступа: http://www. aari.ru/resources/d0004/index.php?dir=Okh/gif/2016/\&sort=name\&order=asc (дата обращения: 11.03.2019).

15. Состояние промысловых ресурсов. Прогноз общего вылова гидробионтов по Дальневосточному рыбохозяйственному бассейну на 2018 г. (краткая версия). Владивосток: ТИНРО-Центр, 2018. 434 с.

\section{References}

1. Zenkovich, P.V. [ed.]. The shores of the Pacific Ocean. Nauka: Moscow, Russia, 1967, 373 p. (In Russian)

2. Zenkovich, V.P. Basics of the doctrine of the development of sea coasts. Publishing House of the Academy of Sciences of the USSR: Moscow, Russia, 1962, 710 p. (In Russian)

3. Brovko, P.F. Development of the lagoon shores of the Far Eastern seas under conditions of rising sea levels. Materials of the XIV Conference of Geographers of Siberia and the Far East. Vladivostok, 2011. 11-14. (In Russian)

4. Brovko, P.F., Vasina, M.V., Dzen, G.N., Zhukovina, M.G., Malyugin, A.V., Menchik, A.A. The lagoons of Sakhalin Island - unique objects of natural heritage. Regional aspects of geographical research and education. Sat articles. Penza, Russia, 2019. 92-95. (In Russian)

5. Bugaev, V.F., Kirichenko, V.E. Rearing and spawning lakes for asian sockeye salmon stocks (including several additional water bodies in range). Kamchatpress Publishing House: Petropavlovsk-Kamchatsky, Russia, 2008. 280 p. (In Russian)

6. Gorin, S.L., Koval, M.V. Lagoons in the tidal estuaries of the Kamchatka and Koryakia rivers. Arctic shores: the path to sustainability. Murmansk, Russia, 2018. 44-47. (In Russian)

7. Brovko, P.F. Recreational-geomorphological systems of the lagoon shores of Sakhalin. Vestnik of the Sakhalin local lore museum. 2013, 20, 190-196. (In Russian)

8. Brovko, P.F., Nguyen, Huu Shiu, Chin, Thee Hieu. Geomorphology and dynamics of the coasts of the Fukhan province (SRV). In Coastal zone of the Far Eastern seas: a collection of scientific papers. Leningrad, Russia, 1991. 119-127 p. (In Russian)

9. Pavlidis, Yu.A., Ionin, A.S., Shcherbakov, F.A. The Arctic shelf. Late Quaternary history as a basis for the forecast of development. Geos: Moscow, Russia, 1998, 187 p. (In Russian)

10. Zhindarev, L.A. Features of the evolution of the lagoon coasts of the Chukchi and Baltic seas. Vestnik MSU. Series 5. 1984, 3. 85-87. (In Russian)

11. Kosyan, P.D., Brovko, P.F., Mikishinetall Yu. The Diversity of Russian Estuaries and Lagoons Exposed to Human Influence. Springer International Publishing, Switzerland, 2017. 270 p.

12. Vladimirov, A.T. Morphology and evolution of the lagoon coast of Sakhalin. In Proceedings of the Institute of Oceanology of the USSR AS. V. XLVIII; Nauka: Moscow, Russia, 1961. 145-171 p. (In Russia)

13. Lymarev, V.I. Arctic Ocean: geosystem aspect. Pomeranian State University: Arkhangelsk, Russia, 2003, 247 p. (In Russian)

14. Ice map of the Sea of Okhotsk. Federal State Budgetary Institution "Arctic and Antarctic Research Institute. Available online: http:/www.aari.ru/resources/d0004/index.php?dir=Okh/gif/2016/\&sort=name\&order=asc (accessed on 1January 2020).

15. The state of fishing resources. Forecast of the total catch of aquatic organisms in the Far Eastern fisheries basin for 2018 (short version). TINRO-Center: Vladivostok, Russia, 2018, 434 p. (In Russian) 